\title{
Du téléphone à micro-ondes au cheval de Troie : quelle culture pour le traducteur spécialisé ?
}

\section{Élisabeth Lavault-Olléon}

\section{(2) OpenEdition}

\section{Journals}

Édition électronique

URL : http://journals.openedition.org/asp/4015

DOI : 10.4000/asp.4015

ISSN : 2108-6354

\section{Éditeur}

Groupe d'étude et de recherche en anglais de spécialité

\section{Édition imprimée}

Date de publication : 1 décembre 1994

Pagination : 45-53

ISSN : 1246-8185

\section{Référence électronique}

Élisabeth Lavault-Olléon, « Du téléphone à micro-ondes au cheval de Troie : quelle culture pour le traducteur spécialisé ? », ASp [En ligne], 5-6 | 1994, mis en ligne le 28 novembre 2013, consulté le 02 mai 2019. URL : http://journals.openedition.org/asp/4015;DOI : 10.4000/asp.4015

Ce document a été généré automatiquement le 2 mai 2019.

Tous droits réservés 


\title{
Du téléphone à micro-ondes au cheval de Troie : quelle culture pour le traducteur spécialisé?
}

\author{
Élisabeth Lavault-Olléon
}

\section{NOTE DE L'ÉDITEUR}

L'auteur de cette contribution n'a pas autorisé sa publication en ligne.

\section{RÉSUMÉS}

À partir d'exemples rencontrés dans des traductions effectuées avec des étudiants traducteurs dans des domaines de spécialité divers, il est donné ici une analyse de la culture nécessaire au traducteur spécialisé. Le concept de culture est redéfini dans cette optique comme une culture pluridisciplinaire de base, qui se construit et évolue grâce à une attitude positive d'investigation et d'acquisition de connaissances fondée sur une démarche consciente et méthodique incluant la recherche documentaire et la mise en relation d'éléments culturels de tous les domaines, y compris de la culture générale.

On the basis of translation examples in a variety of subjects encountered in a translation training course, the author analyses what sort of cultural background is needed by the technical translator. Culture is therefore defined for this particular purpose as basic multidisciplinary culture which is constructed and developed through positive investigation and knowledge 
acquisition. These are obtained by a consciously methodical approach to documentation research and the gathering of cultural elements from all fields of study, including that of "high" culture.

INDEX

Mots-clés : compréhension, pluridisciplinarité, traduction spécialisée

Keywords : pluridisciplinarity, specialised translation

\section{AUTEUR}

\section{ÉLISABETH LAVAULT-OLLÉON}

Élisabeth Lavault-Olléon enseigne au Département des Langues étrangères appliquées de l'Université Stendhal Grenoble 3. Elisabeth.Lavault@u-grenoble3.fr 